\author{
Tomasz Moskal \\ https://orcid.org/0000-0001-7920-0221 \\ Biuro Projektów Tomasz Moskal, Kraków
}

\title{
Problematyka kształtowania śródmieścia miasta. Studia nad rozwojem przestrzennym Rzeszowa
}

\section{The issues of shaping the city centre - studies on the spatial development of Rzeszów}

\begin{abstract}
Streszczenie
Tworzenie śródmieścia miasta odbywa się na drodze ewolucji jako proces przekształceń obejmujących w formie fizycznej zabudowę i infrastrukturę techniczną, a w formie niefizycznej kwestie społeczne i własnościowe. Kiedy proces przekształceń ma charakter płynny, istnieje szansa na budowę układów i form harmonijnych. Kiedy proces ten odbywa się na drodze skokowej, rewolucyjnej, prawdopodobne jest, że pozostawi on ślad w strukturze urbanistycznej. Współczesny kształt przestrzenny Śródmieścia Rzeszowa jest efektem procesu przekształcania pierwotnej struktury jaki odbywał się wraz z dynamicznym rozwojem miasta w latach powojennych. Struktura ta jest odzwierciedleniem podejmowanych działań jak i zaniechań. Artykuł podejmuje problematykę kształtowania śródmieścia miasta w ośrodku szybko rozwijającym się na przykładzie Śródmieścia Rzeszowa.
\end{abstract}

Słowa kluczowe: Rzeszów, centrum miasta, tkanka śródmiejska

\begin{abstract}
The creation of the city centre occurs through evolution as a process of transformations involving buildings and technical infrastructure in a physical form, and social and ownership issues in a non-physical form. When the transformation process is fluid, there is the opportunity to build harmonious systems and forms. When this process takes place in a revolutionary step, it is likely that it will leave a mark on the urban structure. The contemporary spatial shape of Śródmieście Rzeszów is the result of the process of transforming the original structure that occurred along with the dynamic development of the city in the post-war years. This structure reflects both the actions taken and omissions. The article deals with the issues of shaping the city centre in a rapidly developing centre, based on the example of Rzeszów city centre.
\end{abstract}

Keywords: Rzeszów, city centre, downtown tissue 


\section{WSTĘP}

Zajmując się problematyką rozwoju przestrzennego Rzeszowa i badając związane z tym tematem dokumenty, autor zwrócił uwagę na zjawisko, które na potrzeby artykułu opisał jako „porządkowanie Śródmieścia Rzeszowa” lub „porządkowanie” obszaru, który pełni funkcję Śródmieścia Rzeszowa. Zjawisko to w ocenie autora ma związek z procesem przejmowania roli śródmieścia przez strukturę przestrzenną niewykształconą w pełni i niewyposażoną funkcjonalnie w tym celu. Problematyka podjęta w artykule dotyczy śródmieścia miasta w znaczeniu jego części obejmującej historycznie ukształtowane jądro z terenami przyległymi, skupiającej aktywności na polu administracji, handlu czy szeroko pojętych usług, o znacznej koncentracji przestrzennej zabudowy. Posługując się pojęciem centrum miasta w prezentacji, autor bierze pod uwagę historycznie wykształcony układ przestrzenny, stanowiący podstawę jego rozwoju i funkcjonowania.

\section{DELIMITACJA OBSZARU ŚRÓDMIEŚCIA RZESZOWA}

Rozwój Śródmieścia Rzeszowa następował na podstawie rozwiniętego historycznie do początku XX w. układu (Mały Rzeszów), który stanowił trzon i podstawową tkankę miasta o zdefiniowanych granicach (il. 2). W drugiej połowie XIX w. teren miasta oprócz naturalnej granicy, jaką stanowiła od wschodu rzeka Wisłok, domknięty został od północy i zachodu trasami linii kolejowych Kraków-Lwów i Rzeszów-Jasło. Jedynie w kierunku południowym, poza naturalnymi przeszkodami w postaci skarp terasy nadrzecznej, kierunek rozwoju pozostawał otwarty. Do początku lat 30. XX w. na tak zdefiniowanym obszarze skupiała się większość zabudowy oraz aktywności gospodarczej miasta. Historyczny układ urbanistyczny stanowił do poł. lat. 30. XX w. podstawową tkankę funkcjonowania miasta. Obszar ten w sposób naturalny był miejscem zamieszkania, pracy i wypoczynku. Bazę mieszkaniową stanowiła istniejąca zabytkowa substancja. Były to kamienice w zabudowie pierzejowej, jak również wolno stojąca zabudowa willowa. Zabudowa o charakterze miejskim sąsiadowała tu z enklawami zabudowy o charakterze wiejskim oraz terenami uprawnymi. Obszar ten zawierał znaczne rezerwy terenowe stanowiące podstawę dla rozwoju zabudowy i funkcji śródmiejskiej. Na północ od starego miasta w kierunku dworca kolejowego znajdował się słabo zabudowany teren w formie pasa szerokości około $500 \mathrm{~m}$. Podobnie znaczne rezerwy niezabudowanego terenu znajdowały się na zachód od centrum miasta w kierunku dworca linii Rzeszów-Jasło. Dystans między rynkiem starego miasta a stacją kolejową Staroniwa na zachodzie to około $1000 \mathrm{~m}$. Wskazany obszar stanowił znaczną część powierzchni całego miasta liczącego od 1901 r. 7,68 km². Nieregularny kształt obszaru terenów miejskich powodował, że granice linii kolejowych i rzeki stanowiły również granice Rzeszowa i otaczających miasto wiosek. Od wschodu za Wisłokiem była to Drabinianka, od zachodu zaś za linią kolejową była to Staroniwa ${ }^{1}$. 
Współcześnie w strukturze administracyjnej Rzeszowa wyodrębniona została jednostka o nazwie Śródmieście, utworzona zgodnie z Uchwałą z 14 stycznia 2019 na drodze połączenie dotychczas funkcjonujących jednostek Śródmieście Północ i Śródmieście Południe. Granice tej jednostki wyznaczają od północy linia kolejowa, od zachodu al. Ł. Cieplińskiego i al. L. Lisa-Kuli, od południa granica prowadzi przez Plac Śreniawitów i Trasę Zamkową. Od wschodu naturalną granicę stanowi rzeka Wisłok. Zdefiniowany wskazanymi granicami obszar śródmieścia poddany został analizie w niniejszym artykule.

\section{LATA 30 XX W. - POCZĄTEK PROCESU WYODRĘBNIANIA ŚRÓDMIEŚCIA RZESZOWA}

Od poł. lat 30. XX w. w wyniku lokalizacji inwestycji przemysłowych nastąpiło ożywienie rozwoju obejmujące również pojawienie się nowej zabudowy oraz infrastruktury miejskiej. Na początku lat 30. XX w. ludność Rzeszowa liczyła 26,9 tys. mieszkańców przy powierzchni miasta mierzącej 7,68 km². Zgodnie z danymi GUS z grudnia 1931 r. Rzeszów zajmował w województwie Iwowskim drugie miejsce po Lwowie pod względem gęstości zaludnienia (3595 osób km²)². W 1939 r. liczba ludności Rzeszowa wzrosła do 42 tys.

W związku z wzrostem tempa rozwoju miasta spowodowanego lokalizacją w mieście inwestycji COP opracowany został Ogólny Plan Zabudowania Miasta Rzeszowa. Według autorów K. Dziewońskiego i W. Śmigielskiego historycznie uformowane centrum miasta (Mały Rzeszów) miał stać się dzielnicą centralną dla ośrodka liczącego 100-150 tys. mieszkańców. Plan Zabudowania z 1939 r. przyjmujący perspektywę szybkiego rozwoju zakładał koncentryczno-promienisty model ekspansji miasta. Głównym założeniem planu było stworzenie nowych arterii komunikacyjnych odciążających historyczne centrum krzyżujących się na północny-zachód od istniejącego centrum miasta oraz kształtowanie zabudowy w sposób koncentryczny wypełniający wskazane wyżej granice dzielnicy centralnej. Dzielnica centralna obejmowała teren od Dworca PKP na północy do Zwięczycy na południu ograniczony linią kolejową Rzeszów-Jasło na zachodzie i rzeką Wisłok na wschodzie, a przewidywana liczba mieszkańców wynosiła 80 tys. Nie zachowały się rysunki planu prezentujące szczegółowe rozwiązania przestrzenne oraz przewidywany zakres zabudowy w obrębie planowanego śródmieścia. Plan w formie szkicowej ukończono wiosną 1939 r. Do tego czasu dla zaspokojenia głodu mieszkaniowego w śródmieściu wśród nowej zabudowy powstawały głównie obiekty pełniące tę funkcję. Z zachowanej dokumentacji archiwalnej wynika, iż decyzje dotyczące lokalizacji obiektów budowlanych podejmowane były w konsultacji z autorami planu zabudowania. Przyjąć więc można, że również zabudowa mieszkalna realizowana w śródmieściu czy to w formie kamienic czy obiektów willowych głównie jako inicjatywa prywatna powstawała zgodnie z założeniami planu. Wiele przykładów takich kamienic uzupełniających istniejącą zabudowę spotykamy przy ul. Jagiellońskiej 
(nr 12, nr 13). W atrakcyjnej lokalizacji przy zbiegu ul. Asnyka i ul. Sobieskiego, pomiędzy starym miastem a dworcem powstała kamienica, przeznaczona dla dyrektorów Wytwórni Silników nr 2 Państwowych Zakładów Lotniczych. Inne budynki mieszkalne wielorodzinne wznoszone jako obiekty wolno stojące w terenie słabo zabudowanym wskazywały przyszłe kierunki rozwoju śródmieścia. Przy zbiegu ul. Chopina i ul. Leszczyńskiego powstał budynek mieszkalny Funduszu Kwaterunku Wojskowego. Budynki mieszkalne wzniesione w centrum miasta w okresie międzywojennym z uwagi na charakter architektury, wysoki standard i jakość wykonania są dobrymi przykładami kształtowania zabudowy śródmiejskiej miasta. Większe zespoły zabudowy mieszkaniowej w formie osiedli projektowane i realizowane były $z$ dala od centrum. Poza wskazanymi przykładami krótki okres ożywienia inwestycyjno-budowlanego poprzedzający wybuch wojny nie pozostawił trwałych śladów w kształcie przestrzennym miasta. W perspektywicznym planie rozwoju miasta z 1939 r., biorąc pod uwagę przewidywany wzrost liczby mieszkańców na zachód od centrum, rezerwowano tereny mające stanowić przyszłe zaplecze rekreacyjne dzielnicy centralnej. Idea ta podjęta została po wojnie i zrealizowana nad wyraz konsekwentnie w postaci parku noszącego obecnie nazwę Jedności Polonii z Macierzą.

\section{SKUTKI WOJNY I OKUPACJI NIEMIECKIEJ W ŚRÓDMIEŚCIU RZESZOWA}

Skutkiem działań niemieckiego okupanta w okresie drugiej wojny światowej była eksterminacja ludności żydowskiej zamieszkującej Rzeszów. W ogólnej liczbie mieszkańców miasta w 1939 r. wynoszącej 42 tys. ludność żydowska liczyła 14 tys. Eksterminacja żydowskich mieszkańców wywarła istotne skutki społeczne, ale miała również wpływ na jego rozwój przestrzenny. Dla zatarcia śladów eksterminacji niemieccy okupanci zlikwidowali stary cmentarz żydowski zlokalizowany na północny wschód od rynku starego miasta (il. 3).

Pozostałością po działaniach okupanta niemieckiego mających usprawnić komunikację kołową na terenie miasta było przebicie łącznika w ciągu współczesnej ul. Sobieskiego, od ul. Grunwaldzkiej do ul. Bernardyńskiej. Powstała w ten sposób trasa stanowiąca alternatywę dla ciągu prowadzącego przez rynek starego miasta. W okolicy zamku Lubomirskich (obecnie Plac Śreniawitów) dla usprawnienia komunikacji w kierunku Wytwórni Silników PZL Niemcy zlikwidowali część istniejącej w tym miejscu wolno stojącej zabudowy.

Według W. Henniga, który od początku lat 50. XX zajmował się historią rozwoju urbanistycznego Rzeszowa jak również planowaniem przestrzennym miasta, istniały stworzone w okresie okupacji niemieckiej plany likwidacji części zabudowy od rynku starego miasta w kierunku kościoła farnego dla stworzenia reprezentacyjnej przestrzeni miejskiej. Poza wzmianką na ten temat brak dokumentów potwierdzających tę informację ${ }^{3}$. 


\section{RZESZÓW - MIASTO WOJEWÓDZKIE}

Po zakończeniu drugiej wojny światowej oprócz przemysłu pojawił się nowy czynnik decydujący o szybkim rozwoju Rzeszowa. Miasto zyskało rangę ośrodka wojewódzkiego. W tym okresie w wyniku realizacji założeń planu sześcioletniego nastąpił w mieście rozwój przemysłu, który spowodował napływ ludności i głód mieszkaniowy. Istniejąca w centrum miasta zabudowa stanowiła podstawową bazę zaspokajającą rosnące potrzeby. Choć ze względu na funkcję miasta w śródmieściu realizowano przede wszystkim inwestycje związane z potrzebami ośrodka administracji wojewódzkiej powstawały tutaj również inwestycje mieszkaniowe. Tereny te były dobrze skomunikowane i posiadały uzbrojenie, co miało duże znaczenie pod względem ekonomicznym. W latach 40. i 50. XX w. z powodu braków mieszkaniowych w mieście ograniczano wyburzenia. Dopiero w drugiej połowie lat 60 . przystąpiono do realizacji ważnych dla funkcjonowania całego miasta inwestycji komunikacyjnych w postaci tras wschód-zachód i części trasy północ-południe wraz z wiaduktami, które wraz z ul. Chopina odciążały centrum miasta z ruchu kołowego.

\section{KONCEPCJE ROZWOJU PRZESTRZENNEGO RZESZOWA AUTORSTWA ZBIGNIEWA WZORKA}

Na przełomie lat 40. i 50. XX w. powstał Ogólny Plan Zagospodarowania Przestrzennego Rzeszowa oraz Plan Zagospodarowania Przestrzennego Śródmieścia. Były to pierwsze powojenne opracowania autorstwa architekta Zbigniewa Wzorka zawierające koncepcję rozwoju Rzeszowa oraz jego śródmieścia nawiązujące do założeń planu z 1939 r. Opracowanie planu śródmieścia w dokumentacji Z. Wzorka stanowiło rozwinięcie i uszczegółowienie planu ogólnego miasta.

W zbiorach Archiwum Biura Rozwoju Miasta Rzeszowa (BRMRz) zachowała się graficzna część opracowania Ogólnego Planu Zagospodarowania Przestrzennego Rzeszowa (il. 4). Jest to rysunek wykonany na podkładzie geodezyjnym w skali 1:5000, opracowany na papierze w konwencji barwnej w trzech połączonych ze sobą częściach naklejonych na tekturze. W dole planszy znajduje się sygnatura potwierdzająca włączenie dokumentu do Archiwum Urzędu Wojewódzkiego w Rzeszowie z datą 14 maja 1955 r. Autorstwo planu stwierdzić można na podstawie podobieństw do planu śródmieścia sygnowanego przez jego autora Z. Wzorka.

Istnieją dwa źródła dokumentacji Planu Zagospodarowania Przestrzennego Śródmieścia Rzeszowa. Pierwsze z nich to archiwum prywatne syna autora planu, Piotra Wzorka. W zbiorze tym zachowała się część opisowa dokumentacji Studium do Planu Miasta Rzeszowa (14 stron maszynopisu) ze stroną tytułową sygnowaną przez Z. Wzorka, opatrzoną datą 1951/52. Drugą część dokumentacji opisowej stanowi część opatrzona tytułem Kompozycja 
Planu Śródmieścia (10 stron maszynopisu, numerowanych oraz 8 stron nienumerowanych). Część opisową uzupełnia część graficzna, którą stanowią odbitki fotograficzne map oraz grafik sylwety miasta, jak również rysunki analizy kompozycyjnej historycznego układu przestrzennego. W zbiorze tym należy zwrócić uwagę na plansze przedstawiające analizę rysunkową sylwety Rzeszowa w formie reprodukcji fotograficznej oraz na kopię fotograficzną rysunku będącego analizą historycznego układu przestrzennego rezydencjonalnego założenia Lubomirskich.

Drugim źródłem archiwalnej dokumentacji opracowania Z. Wzorka jest Archiwum Biura Rozwoju Miasta Rzeszowa. W zbiorze tym część opisowa Studium do Planu Miasta Rzeszowa zachowała się w stanie częściowym (od strony 6). Dalsza część opisu z nagłówkiem Kompozycja Planu Śródmieścia zachowała się w pełnym zakresie z ciągłą, odręcznie wprowadzoną numeracją stron. W tym zbiorze dokumentacji szczególnie cenny jest rysunek projektu Planu Śródmieścia Rzeszowa w postaci odbitki fotograficznej na planszy A3 (il. 5). Dodatkowo wśród dokumentacji fotograficznej znajdują się również odbitki przedstawiające warianty rysunkowe planowanego w okolicach ul. Słowackiego i ul. Szopena założenia urbanistycznego wiążącego dawny zamek Lubomirskich z planowanym teatrem. Dokumentacja ta zawiera również analizę rysunkową historycznej sylwety miasta w ujęciu od strony wschodniej i zachodniej oraz dokumentację fotograficzną.

W założeniach planu dynamiczny rozwój struktury 100-150 tys. ośrodka powodował, że historyczny układ przestrzenny tracił możliwość jego obsługi. Nowa funkcja ośrodka centralnego dla rozległego województwa wymagała zastosowania rozwiązań zaspokajających jego potrzeby i jednoznacznie definiujących śródmiejski charakter centrum miasta. Koncepcja planu przewidywała wprowadzenie do śródmieścia nowych zespołów zabudowy dla pomieszczenia funkcji związanej z zadaniami miasta wojewódzkiego, w tym również zabudowy mieszkaniowej. Z zachowanej dokumentacji nie wynika jasno, jaki był planowany udział zabudowy mieszkaniowej w projektowanym śródmieściu. Z. Wzorek zwraca uwagę, iż wśród planowanej nowej zabudowy przeznaczonej na cele biurowe przewidzieć należy również funkcję mieszkaniową „...dla wypełnienia życia w godzinach wieczornych" ${ }^{4}$.

Autor planu kładł duży nacisk na tworzenie reprezentacyjnych przestrzeni odpowiadających nowej funkcji miasta tak w skali ogólnej jak i w śródmieściu. Przestrzenie te w skali całego miasta i śródmieścia pełniły rolę punktów węzłowych łączących poszczególne jednostki. W osiągnięciu tego celu istotną rolę odgrywały czynniki kompozycyjne. W rozwiązaniach projektowych proponowanych dla terenów śródmieścia autor nawiązał do elementów historycznego układu przestrzennego rezydencjonalnego założenia Lubomirskich (il. 7). W planie miasta rzeka Wisłok miała stanowić element jego wewnętrznej kompozycji. Nowe arterie na kierunkach wschód-zachód oraz północ-południe miały zapewnić sprawną komunikację w skali całego miasta odciążając jego zabytkowe centrum. To wzdłuż tych ciągów miało kształtować się nowe śródmieście miasta z reprezentacyjną zabudową. Szczególnie wiele uwagi poświecił Z. Wzorek kształtowaniu zabudowy wzdłuż trasy 
wschód-zachód, mając świadomość, że decydować będzie o wyglądzie i odbiorze reprezentacyjnej części śródmieścia. Należy zwrócić uwagę na zaakcentowanie w sposobie kształtowania linii zabudowy skrzyżowania obu wspomnianych tras. Autor, przewidując zabudowę pierzejową ciągów, starał się uporządkować rozległą i niezdefiniowaną dotychczas w tym miejscu przestrzeń z klasztorem i kościołem bernardynów oraz dominującą bryłę gmachu Wojewódzkiej Rady Narodowej (WRN) oraz to, że „węzeł projektowanych arterii wschód-zachód i północ-południe wymagał architektonicznej obudowy"5.

Realizacja trasy wschód-zachód nastąpiła dopiero pod koniec lat 60. XX w., kiedy powstał też wiadukt (Śląski) nad linią kolejową Rzeszów-Jasło. Trasa północ-południe zrealizowana została częściowo. Powstał wiadukt tarnobrzeski, ale wytyczona z rozmachem dalej na południe arteria kończyła się w okolicach budynku zakładów graficznych, wprowadzając ruch kołowy w nieprzystosowane do tego celu ulice starej części miasta.

Pasmo zabudowy wschód-zachód (il. 6) porządkujące zabudowę terenów pomiędzy starym miastem a rejonem dworca PKP ukształtowane na podstawie arterii komunikacyjnej o charakterze tranzytowym oraz równoległej do niej prowadzącej od strony południowej ulicy (obecnie ul. Sobieskiego). W opisie do planu Z. Wzorek zwracał uwagę, iż „Teren między starym miastem a linią kolejową i umieszczonym na niej dworcem grupuje najbardziej haotyczną [sic!] zabudowę z całości miasta. (...) Przemieszanie budownictwa spekulacyjnego - domów czynszowych z warsztatami rzemieślniczymi w oficynowych budynkach i średniej wielkości zakładami przemysłowymi wraz z wolnostojącymi budynkami, tworzy szczególny obraz bezplanowo wznoszonego miasta"6. Pasmo to, wypełnione głównie nową zabudową, miało pełnić rolę centrum administracyjnego.

Od wschodu rozpoczynało się ono placem na miejscu dawnego rynku nowego miasta, a od zachodu elementem domykającym był gmach siedziby WRN i otwarta przestrzeń dawnych ogrodów bernardyńskich, gdzie w przyszłości pojawić miał się pomnik Czynu Rewolucyjnego. W wariantach opracowania tego pasma pojawiał się ciąg pieszy prowadzony jego wnętrzem. Oprawa architektoniczna reprezentacyjnej arterii miasta al. Lenina (obecnie al. Piłsudskiego) miała zostać wzbogacona szpalerem drzew. Z. Wzorek wskazywał, iż decyzja o lokalizacji siedziby WRN ze względu na nadmierną skalę oraz brak ujęcia całości bezpośredniego otoczenia może stwarzać trudności w kompozycyjnym ujęciu tej części miasta7. Autor zwracał również uwagę, iż budynek WRN powstał wbrew jego opinii ${ }^{8}$. W ramach tego pasma powstało założenie obejmujące teren zlikwidowanego przez Niemców starego cmentarza żydowskiego, na którego terenie powstał skwer i park. Oś założenia połączyła budynek Komitetu Wojewódzkiego PZPR zrealizowany w pierzei północnej obecnej al. Piłsudskiego z pomnikiem Wdzięczności Armii Radzieckiej. Ramy architektoniczne tej przestrzeni dopełniła zabudowa istniejąca jak i projektowana w tym budynek Wojewódzkiej Komisji Planowania Gospodarczego. Inne zrealizowane elementy tego pasma to budynki mieszkalne przy ul. Sobieskiego (niegdyś ul. 1 Maja) i ul. Asnyka.

W południowej części śródmieścia Z. Wzorek zaproponował rozwiązania przestrzenne nawiązujące do elementów założenia rezydencjonalnego Lubomirskich z XVIII w. Oś 
kompozycyjna zespołu dawnych stajni zamkowych zachowana w ciągu ul. L. Lisa-Kuli (dawniej ul. Zamkowa) stanowiła postawę założenia scalającego istniejący układ komunikacyjny z nowo projektowaną arterią północ-południe (il. 7). Zwornikiem tej koncepcji miał być plac z akcentującym przestrzeń pomnikiem bądź budynkiem. Założenie Zamek Lubomirskich - Teatr (il. 7, 8) przewidywało skwer lub w innym wariancie założenie wodne w oprawie architektonicznej pomiędzy zamkiem Lubomirskich a planowanym na wschód od niego budynkiem teatru w rejonie dzisiejszej ul. Słowackiego. Realizacja tej koncepcji wymagała likwidacji istniejącej w tym miejscu zabudowy mieszkaniowej (ul. PCK), stąd nie doczekała się ona realizacji. Miejsce planowanego teatru zajął wzniesiony w latach 70. XX w. po drugiej stronie ul. Słowackiego budynek Filharmonii im. A. Malawskiego.

Z. Wzorek zwracał uwagę na jego zdaniem błędne decyzje lokalizacyjne dotyczące powstających w śródmieściu obiektów. Błędem według Wzorka była lokalizacja internatu Zespołu Szkół Budowlanych w rejonie skrzyżowania głównych ciągów komunikacyjnych obecnych al. Ł. Cieplińskiego i al. J. Piłsudskiego. Miejsce to według architekta powinien był zająć budynek o charakterze reprezentacyjnym a „koncepcja usytuowania internatu... wynika z niedocenienia roli tego punktu w planie miasta, jak również z niedocenienia wartości terenów śródmiejskich - rosnącego 100-tysięcznego miasta"9.

\section{PLANY I REALIZACJE}

Plany Z. Wzorka dotyczące tak miasta w całości, jak i śródmieścia nie miały charakteru dokumentów obowiązujących. Analizując jednak kształt przestrzenny miasta, można stwierdzić, iż wiele istniejących obiektów (szczególnie tych zrealizowanych w latach 50. i 60. XX w.) oraz fragmenty współczesnej tkanki urbanistycznej realizują ich założenia. W rzeczywistości niedoborów realizacja koncepcji przewidzianych w planach Z. Wzorka miała charakter szczątkowy. W powojennej sytuacji społeczno-gospodarczej inwestycje budowlane w Rzeszowie powstawały niemal wyłącznie z inicjatywy władzy i realizowały jej potrzeby. Przy skrzyżowaniu ul. Grunwaldzkiej i ówczesnej al. Lenina (obecnie al. Piłsudskiego) powstał budynek WRN stanowiący element koncepcji pasa wschód-zachód. Gmach komitetu KW PZPR zrealizowany po północnej stronie al. Lenina (obecnie ul. Piłsudskiego) wraz z założeniem obejmującym park i skwer powstały na miejscu starego cmentarza żydowskiego oraz otaczającą zabudową stanowił również zrealizowany element pasa wschód-zachód.

W dziedzinie komunikacji plan Z. Wzorka rozwijał koncepcję zarysowaną już w planie z 1939 r. Do czasu realizacji inwestycji drogowych obejmujących budowę wiaduktów nad liniami kolejowymi obszar przeznaczony do sprawowania funkcji śródmiejskich posiadał ograniczenia w komunikacji z resztą rozwijającego się miasta. Rozwiązania projektowe przewidywały wprowadzenie tras wschód-zachód i północ-południe, odciążających centrum miasta. Ich planowany przebieg krzyżował się z uformowanymi ciągami komunikacyjnymi. 
Były to przede wszystkim ulice łączące stare miasto z terenami dworca kolejowego z pierzejowo formowaną zabudową. Nowe przebicia komunikacyjne penetrowały tereny, które stanowiły zaplecze istniejących ciągów ukazując chaotyczną zabudowę, nieatrakcyjne podwórka kamienic, szopy czy zaniedbane ściany szczytowe (il. 9).

Problem ten dotyczył al. Piłsudskiego (dawniej al. Lenina), która miała stanowić główny ciąg komunikacyjny w tej części miasta. Głównym założeniem Wzorka było uzupełnienie istniejącej zabudowy w taki sposób, aby zniknęły blizny świadczące o ingerencji w pierwotny układ i tkankę miasta. W latach 60 XX w. ciężar inwestycji mający na celu zaspokojenie potrzeb mieszkaniowych został przeniesiony poza teren śródmieścia. Ograniczona skala realizacji założeń planów Wzorka oraz brak ich kontynuacji w kolejnych latach spowodowały utrwalenie się niekorzystnych śladów szybkich przemian i utrwalenie przejściowego i prowizorycznego charakteru struktur przestrzennych. W obszarze miasta zdefiniowanym dla potrzeb opracowania jako śródmiejski funkcjonowały rejony w żadnym względzie nie spełniające tej definicji.

Ciąg al. Piłsudskiego w obrębie śródmieścia jest czytelnym zapisem ingerencji w istniejącą strukturę przestrzenną. Ingerencja ta pozbawiona była wiodącej idei i konsekwencji. Trasa ta wraz z towarzyszącą zabudową miała definiować nową śródmiejską przestrzeń miasta. Poza nielicznymi realizacjami nowej zabudowy zachowały się tutaj elementy zabudowy oraz słabo powiązane w spójną całość fragmenty dawnych układów przestrzennych, co nie było korzystne dla odbioru całego założenia.

\section{ALTERNATYWNE KONCEPCJE ROZWOJU ŚRÓDMIEŚCIA}

W latach 50. XX w. pojawiła się koncepcja przewidująca wprowadzenie do Śródmieścia Rzeszowa na większą skalę zabudowy mieszkaniowej. Tereny w centrum miasta były dostępne inwestycyjnie ze względu na obecność infrastruktury technicznej. W latach 1954-1955 w pracowni Biura Urbanistycznego Warszawy powstał projekt planu szczegółowego zagospodarowania przestrzennego Śródmieścia Rzeszowa. W zbadanej dokumentacji brak informacji na temat przyczyn zlecenia alternatywnego opracowania. Projekt dotyczył obszaru o powierzchni 212 ha, na którym przewidziano program intensywnego budownictwa mieszkaniowego dla 32 tys. mieszkańców przy jednoczesnym ograniczeniu obiektów użyteczności publicznej. Proponowana intensywność przekraczała przyjęty w założeniach wyjściowych poziom 24 tys. mieszkańców. Nie zachowała się dokumentacja planu pozwalająca na ocenę rozwiązań przestrzennych. Z zachowanych informacji wiadomo, że zabudowa miała nie przekraczać wysokości czterech kondygnacji, a nieliczne wyższe obiekty miały stanowić dopełnienie zabytkowej sylwety miasta ${ }^{10}$. 


\section{PROBLEM DELIMITACJA OBSZARU ŚRÓDMIEJSKIEGO RZESZOWA}

Skutkiem przejścia od skali niewielkiego miasta do roli centrum ośrodka w Śródmieściu Rzeszowa było utrwalenie niejednorodnej struktury przestrzennej i funkcjonalnej. Pomimo ciekawych koncepcji kształtowania przestrzeni zaproponowanych przez Z. Wzorka ograniczony zakres inwestycji nie pozwolił na jednoznaczne zdefiniowanie charakteru i ukształtowanie tkanki przestrzennej obszaru Śródmieścia Rzeszowa właściwej dla ośrodka tej skali.

$\mathrm{Na}$ problem w określeniu granic obszaru śródmiejskiego Rzeszowa uwagę zwracał w 1971 r. S. Juchnowicz w książce Śródmieścia miast polskich. Studia nad ukształtowaniem i rozwojem centrów. Zdaniem autora w Rzeszowie układ centrum i jego zasięg nie pozostawał w ścisłym związku z układem przestrzennym a funkcje śródmiejskie koncentrowały się w wybranych blokach zabudowy lub ich częściach. Istniały tutaj również duże kontrasty w sposobie użytkowania terenu. W części wschodniej i zachodniej śródmieścia przy słabo wykształconym układzie urbanistycznym zabudowa typu miejskiego graniczyła z enklawami zabudowy o charakterze niemal wiejskim. Realizacja obiektów usługowych w części północnej śródmieścia nie łączyła w sposób harmonijny pod względem funkcjonalnym i przestrzennym tej części miasta ${ }^{11}$. Diagnoza ta postawiona została na początku lat 70. XX w., a więc stanowiła podsumowanie 25 lat rozwoju Rzeszowa jako ośrodka wojewódzkiego i kształtowania się jego śródmieścia.

S. Juchnowicz zwracał uwagę, iż zadaniem urbanistyki po wojnie była odbudowa zniszczonych miast i szybka ich rozbudowa wskutek założonych procesów industrializacji, a osiągnięcia w tej dziedzinie najsłabiej uwidoczniły się w prawidłowej przebudowie śródmieść i centrów miejskich. Jako przyczynę tego stanu autor wskazywał niedorozwój dziedziny usług, spowodowany w pierwszym okresie powojennym słabością ekonomiczną państwa, a w okresach późniejszych zachwianiem proporcji pomiędzy rozwojem sfery produkcji a sferą usług ${ }^{12}$.

\section{PORZĄDKOWANIE CHAOSU}

W październiku 1956 r. odbył się w Rzeszowie Regionalny Pokaz Architektury, w ramach którego odbyła się prezentacja dorobku architektonicznego i urbanistycznego młodego województwa. W trakcie dyskusji towarzyszących Pokazowi pojawiały się głosy krytyczne dotyczące kierunków rozwoju urbanistycznego miasta. „Miasto nie posiada czytelnego układu kompozycyjnego. Zagmatwane i ciasno zabudowane centrum nie sprzyja poprawie tego stanu. Stare miasto posiada ciekawą sylwetę, która w całości jest widoczna ze wzgórz i wlotów od wschodu i zachodu"13. Podczas dyskusji omawiano również temat adaptacji istniejącej zabudowy zespołu staromiejskiego do wymagań roli centrum miasta ośrodka wojewódzkiego. Szczególne kontrowersje wśród uczestników 
dyskusji wywołała ingerencja w kształt i wystrój architektoniczny elewacji kamienic w północnej części ul. 3 Maja. Zastosowano tam rozwiązania ingerujące w historyczne formy architektoniczne poprzez wprowadzenie przeszkleń wielkopowierzchniowych, stosowanie zadaszeń obejmujących rząd sąsiadujących kamienic czy elementy wystroju elewacji. Jednoznacznym głosem krytyki była opinia arch. Janusza Ingardena, według którego „modernizacja starych kamieniczek jest zaprzeczeniem wyników wszystkich dotychczasowych dyskusji w podobnych sprawach"14. Pomimo upływu czasu jakość przestrzeni Śródmieścia Rzeszowa nie ulegała znacznej poprawie, a w dynamicznie rozwijającym się ośrodku wojewódzkim, jakim był Rzeszów u progu lat 70. XX w. wzrastały oczekiwania wobec kształtu tej części miasta. W 1973 r. rzeszowski oddział SARP zorganizował Ogólnopolski Konkurs na opracowanie koncepcji urbanistyczno-architektonicznej Centrum Usługowego Rzeszowa. Według organizatorów poszukiwanie nowych rozwiązań dla centrum Rzeszowa wynikało z faktu, iż ciągły i intensywny rozwój miasta doprowadził do przypadkowego rozmieszczenia usług handlowych, gastronomicznych i administracyjnych, przy jednoczesnym występowaniu na terenie śródmieścia istniejących, nietypowych dla tego obszaru, funkcji takich jak: mieszkalnictwo, szkoły, składy, ogrody, sady itp. Brak wyraźnego systemu komunikacyjnego, komunikacji kołowej, pieszej i parkingów, uniemożliwiał podejmowanie decyzji lokalizacyjnych dla wielu centrotwórczych obiektów ${ }^{15}$. Konkurs miał stanowić odpowiedź na pytanie jak ma wyglądać centrum miasta, które odpowiadałoby rangą zarysowującej się w budownictwie mieszkaniowym czy układach komunikacyjnych skali rozwoju Rzeszowa. W poszukiwanych rozwiązaniach chodziło nie tylko o zwykłą koncentrację usług o odpowiednim programie, ale również, aby to przyszłe centrum obok funkcjonalności, nowoczesności, rozmachu, miało własny, indywidualny, niepowtarzalny wyraz i żeby ten swój charakter nadało całemu miastu, wyróżniając go spośród innych"16.

Współautor jednej z wyróżnionych w konkursie prac, architekt Jerzy Gurawski, postrzegał Rzeszów w 1973 r. jako miasto rozległe i obszerne, w którym atrakcyjne relikty architektury są nieczytelne z powodu bałaganu przestrzennego, gdzie stare miasto ginie w lawinie drobnej zabudowy otoczenia, a istniejący kiedyś ciąg historyczny przyjął rolę komunikacji ${ }^{17}$.

W odpowiedzi na tak sformułowane założenia powstały koncepcje w sposób zdecydowany ingerujące w istniejący układ przestrzenny. Autorzy prac konkursowych proponowali skupiska zespołów zabudowy o mocno zindywidualizowanym charakterze przenikające i często dominujące tkankę śródmieścia. Wśród tych koncepcji projekt zwycięski wyróżniało poszanowanie istniejącego układu przestrzennego oraz odpowiednia skala i forma planowanej zabudowy (il. 11). Projekt ten opracowany został przez zespół architektów SARP w Rzeszowie (S. Wantuch, T. Karyś, J. Trzeciak, A. Kraus, K. Ferenc). 


\section{ŚRÓDMIEŚCIE - ZIELEŃ - WODA}

W wyniku ograniczonej skali przekształceń w obrębie Śródmieścia Rzeszowa zachowało się tutaj sporo enklaw zieleni. Niewielka powierzchnia tego obszaru była atutem, jeśli chodzi o dostęp do otaczających terenów zielonych. Na wschód od starego miasta znajdował się zadrzewiony teren starego cmentarza stykający się z terenem zielonym położonym wzdłuż Wisłoka. Dalej na południe w górę rzeki w bezpośrednim sąsiedztwie śródmieścia położone były Olszynki pełniące funkcję rekreacyjne. Na terenach pomiędzy starym miastem a linią kolejową Rzeszów-Jasło w okresie powojennym powstały tereny rekreacyjne z parkiem (obecnie park Jedności Polonii z Macierzą) oraz zespołem obiektów sportowych.

Bezpośrednie sąsiedztwo Wisłoka w przeszłości miasta było atutem ze względów obronnych. Kiedy czynnik ten stracił na znaczeniu, rzeka stała się raczej barierą ograniczającą rozwój i niepowiązaną z miastem. Od strony rzeki miasto lokowało funkcje nieatrakcyjne i uciążliwe, takie jak cmentarz, gazownia, elektrownia. Można stwierdzić, że Śródmieście Rzeszowa "opierało" się o rzekę lub nawet, że było od niej „odwrócone”. Od strony rzeki brak było inwestycji o charakterze centrotwórczym. Były to peryferie miasta. Do momentu budowy mostu na zaporze spiętrzającej wodę na Wisłoku w 1974 r. miasto posiadało tylko jedną przeprawę mostową (most Lwowski) do części prawobrzeżnej. Skutkiem tego był całkowity brak powiązań między śródmieściem a powstającym na wschodzie Nowym Miastem. Dopiero realizacja długo wyczekiwanego mostu zamkowego w pobliżu dawnej siedziby Lubomirskich pozwoliła na stworzenie powiązania śródmieścia z dynamicznie rozwijająca się wschodnią dzielnicą.

W połowie lat 60 . powstała koncepcja utworzenia zespołu terenów zielonych w nawiązaniu do doliny Wisłoka od mostu Lwowskiego w górę rzeki aż po Lisią Górę. Realizacją części tego projektu jest park Kultury i Wypoczynku. Powstały tereny zielone niestety słabo powiązane z centrum miasta, egzystujące na zapleczu śródmieścia.

\section{PODSUMOWANIE}

W tkance urbanistycznej i architekturze Śródmieścia Rzeszowa zakonserwowany został zapis procesu przejścia od skali miasta małego o znaczeniu lokalnym do ośrodka pełniącego funkcje ponadlokalne o złożonych zadaniach i szerszych aspiracjach. Charakter przemian i procesów społeczno-gospodarczych spowodował powstanie w obrębie Śródmieścia Rzeszowa obszarów o słabo wykształconym układzie urbanistycznym, gdzie zabudowa typu miejskiego graniczyła z enklawami zabudowy o charakterze niemal wiejskim. Utrwalenie tego stanu spowodowane było $w$ dużej mierze ograniczeniem wyburzeń $i$ brakiem konsekwencji w realizacji koncepcji urbanistycznych zapisywanych w planach zagospodarowania 
przestrzennego w okresie powojennym. Zachowanie zabudowy zabezpieczającej podstawowe i najważniejsze potrzeby mieszkaniowe spowodowało ograniczenie przekształceń w obrębie Śródmieścia Rzeszowa. Wprowadzenie do śródmieścia funkcji mieszkaniowej w nieodpowiedniej skali spowodowało powstanie enklaw tego typu zabudowy niewyposażonych w funkcje uzupełniające (zabudowa w okolicy ul. Słowackiego i ul. Chopina) i ograniczenie możliwości ekspansji funkcji śródmiejskiej.

Wprowadzenie nowych przebić komunikacyjnych i brak realizacji odpowiedniej zabudowy towarzyszącej było przyczyną pojawienia się w kształtującym się centrum miasta niezdefiniowanych przestrzeni i mało atrakcyjnych w odbiorze widoków (zaplecza kamienic, zabudowa gospodarcza, ściany szczytowe). Stan ten z powodu ograniczonych działań inwestycyjnych w wielu miejscach utrwalił się na lata.

Brak połączeń komunikacyjnych do części prawobrzeżnej miasta ograniczył rozwój funkcji śródmiejskich od strony rzeki i ich powiązanie z terenami nadrzecznymi. Dzielnica Nowe Miasto rozwijająca się na prawym brzegu Wisłoka, nieodległa wobec śródmieścia pod względem rzeczywistego dystansu do 2002 r. nie posiadała z centrum miasta bezpośredniego połączenia komunikacyjnego.

Błędne decyzje dotyczące lokalizacji w obrębie śródmieścia obiektów o przeznaczeniu niezwiązanym z charakterem i funkcją śródmiejską spowodowały powstawanie enklaw negatywnie wpływających na kształtowanie tej dzielnicy. Takim przykładem jest lokalizacja budynku centrali telefonicznej w centrum miasta, przy al. J. Piłsudskiego. Prorocza również okazała się diagnoza Z. Wzorka dotycząca lokalizacji budynku internatu Zespołu Szkół Budowlanych w obrębie śródmieścia. Znalazła ona spełnienie w decyzji o przebudowie tego obiektu na siedzibę Urzędu Marszałkowskiego zrealizowanej w 2009 r.

Brak ciągłości funkcjonalnej i przestrzennej w obrębie centrum miasta w ocenie autora był w przeszłości i pozostaje nadal przyczyną problemu z wskazaniem rzeczywistego zasięgu Śródmieścia Rzeszowa. Tkanka urbanistyczna i architektura miasta jest zapisem jego losów, doświadczeń, jak również aspiracji gospodarzy. Tak też dzieje się w przypadku Rzeszowa miasta, którego doświadczeniem były i są dynamiczne zmiany. W przestrzeni Śródmieścia Rzeszowa ciągle obecne są i widoczne ślady przekształceń przestrzennych zapoczątkowane w okresie powojennym. Są to miejsca w tkance zabudowy, które jeszcze się nie zabliźniły i czekają, kiedy zastosowane zostaną właściwe dla śródmieścia tej skali miasta rozwiązania funkcjonalne, architektoniczne i urbanistyczne. 

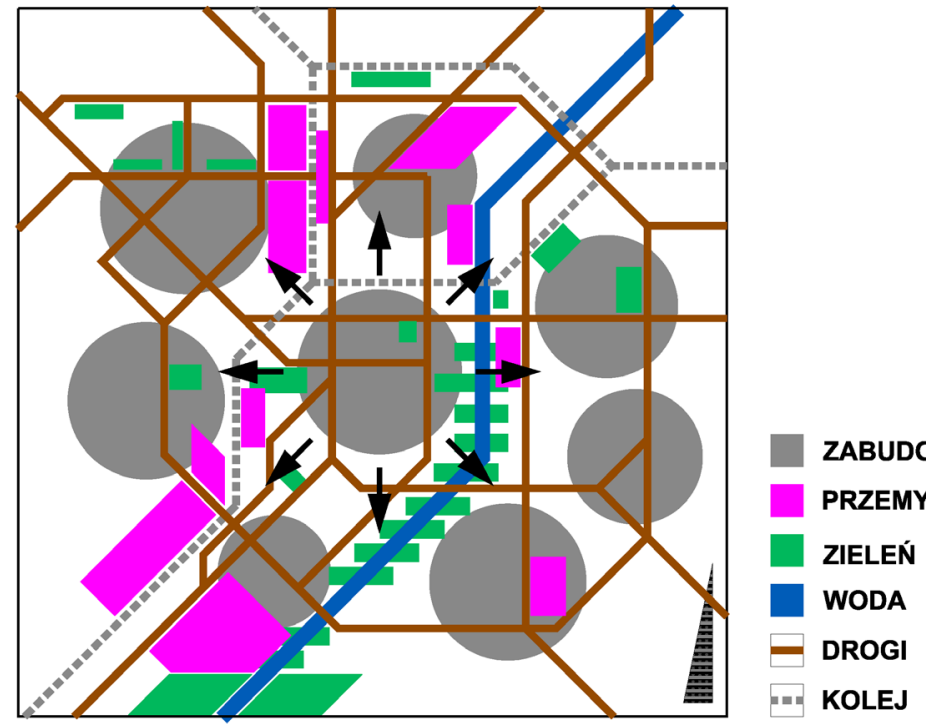

II. 1. Śródmieście w strukturze przestrzennej Rzeszowa w połowie lat 70. XX w. Diagram (opracowanie własne)

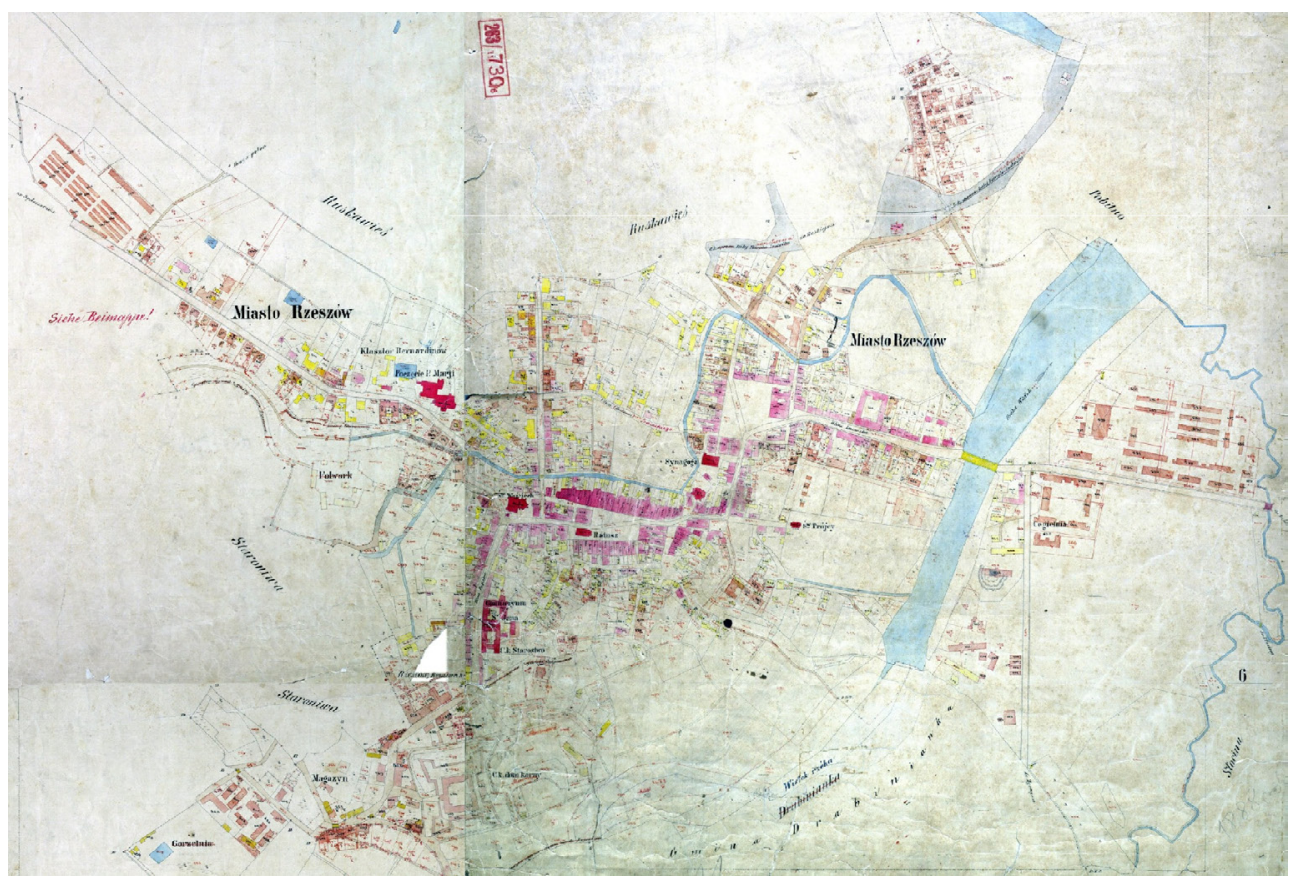

II. 2. Plan katastralny Rzeszowa z 1888 r. Źródło: The Gesher Galicia Map Room (https://maps. geshergalicia.org/cadastral/rzeszow-1888, dostęp: 10.04.2018) 


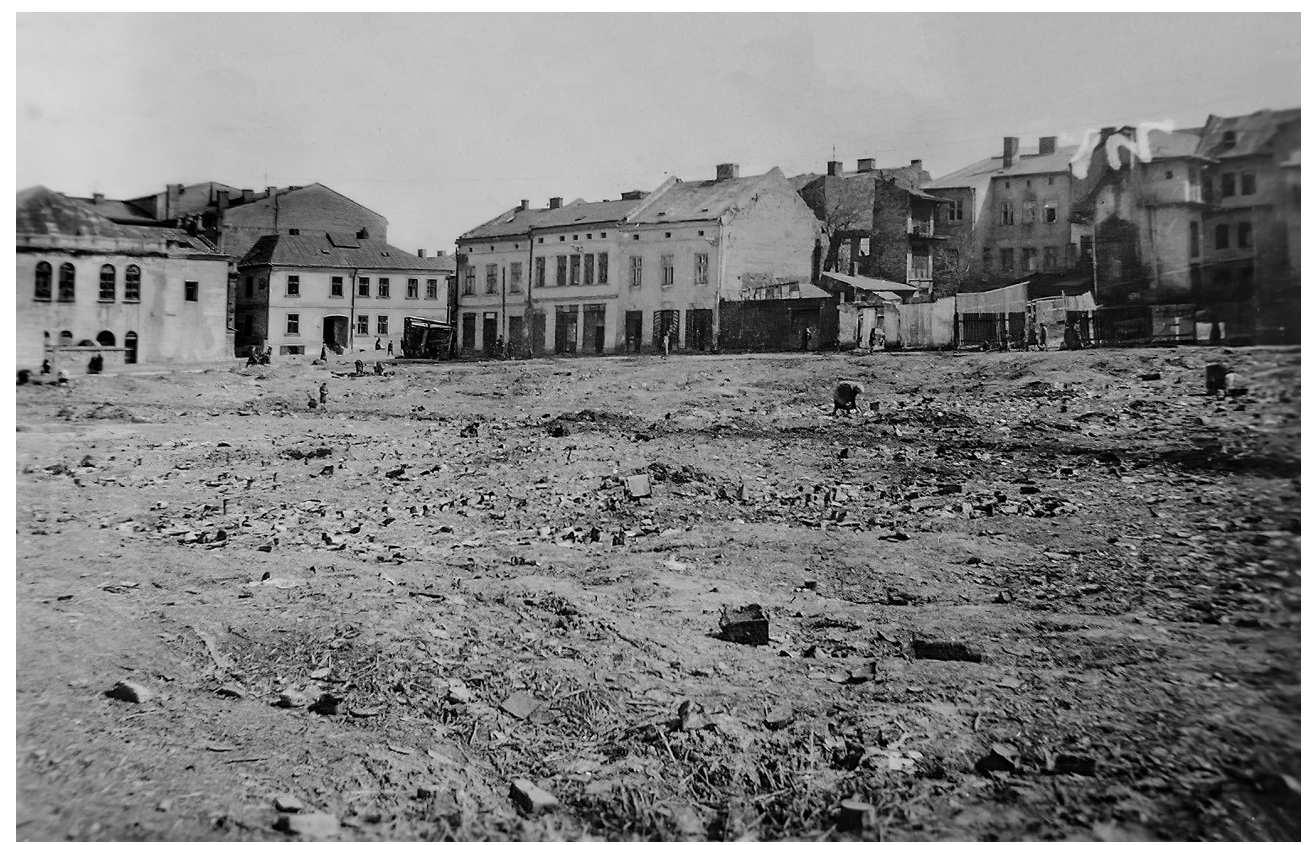

II. 3. Teren zlikwidowanego przez Niemców starego cmentarza żydowskiego (źródło: Rzeszów Wczoraj i Dziś, https://www.facebook.comphotofbid=3156345851100452\&set=a.2254924454575934, 


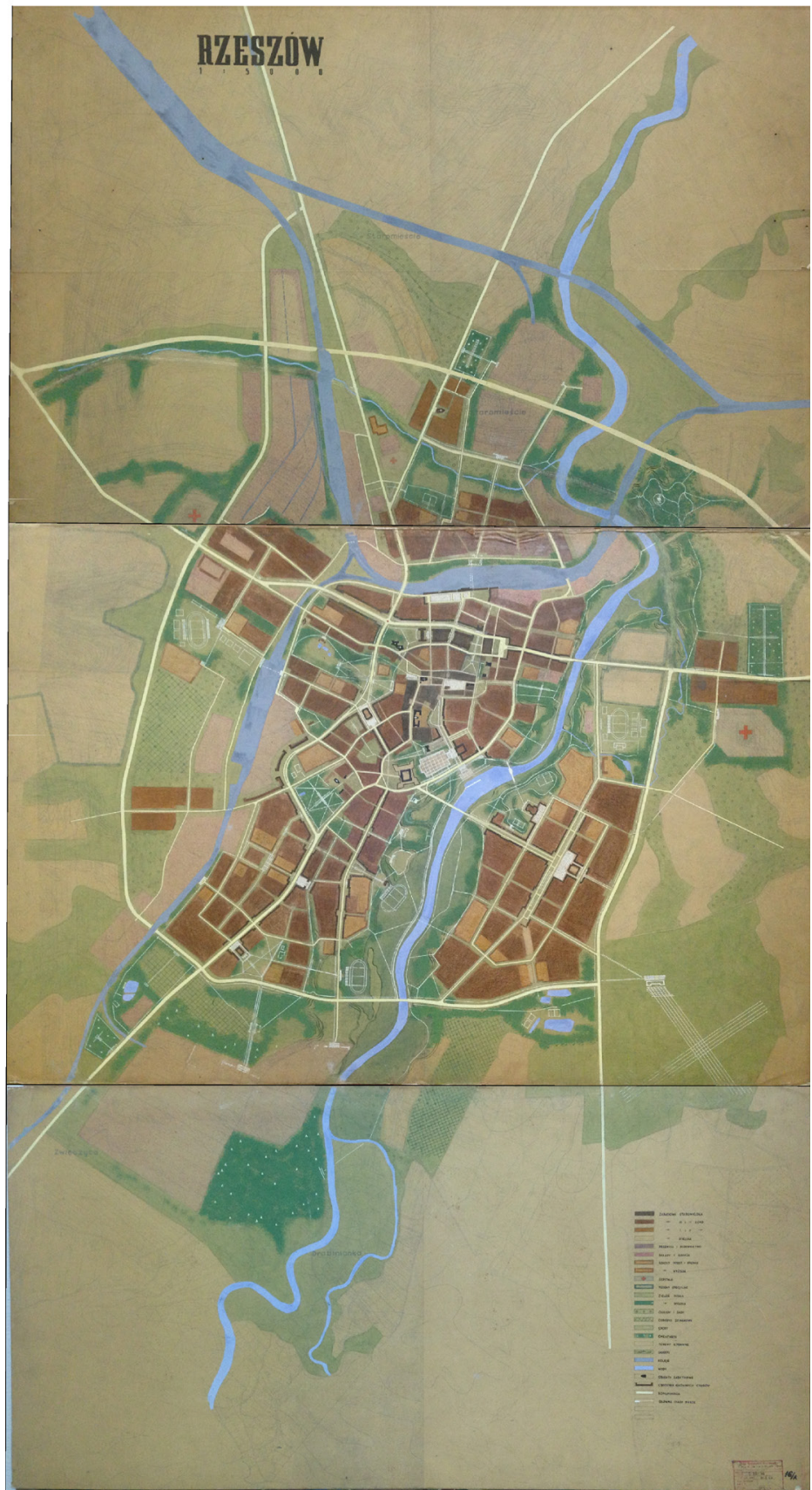

II. 4. Plan ogólny zagospodarowania przestrzennego Rzeszowa autorstwa Z. Wzorka (źródło: Archiwum BRMRz) 


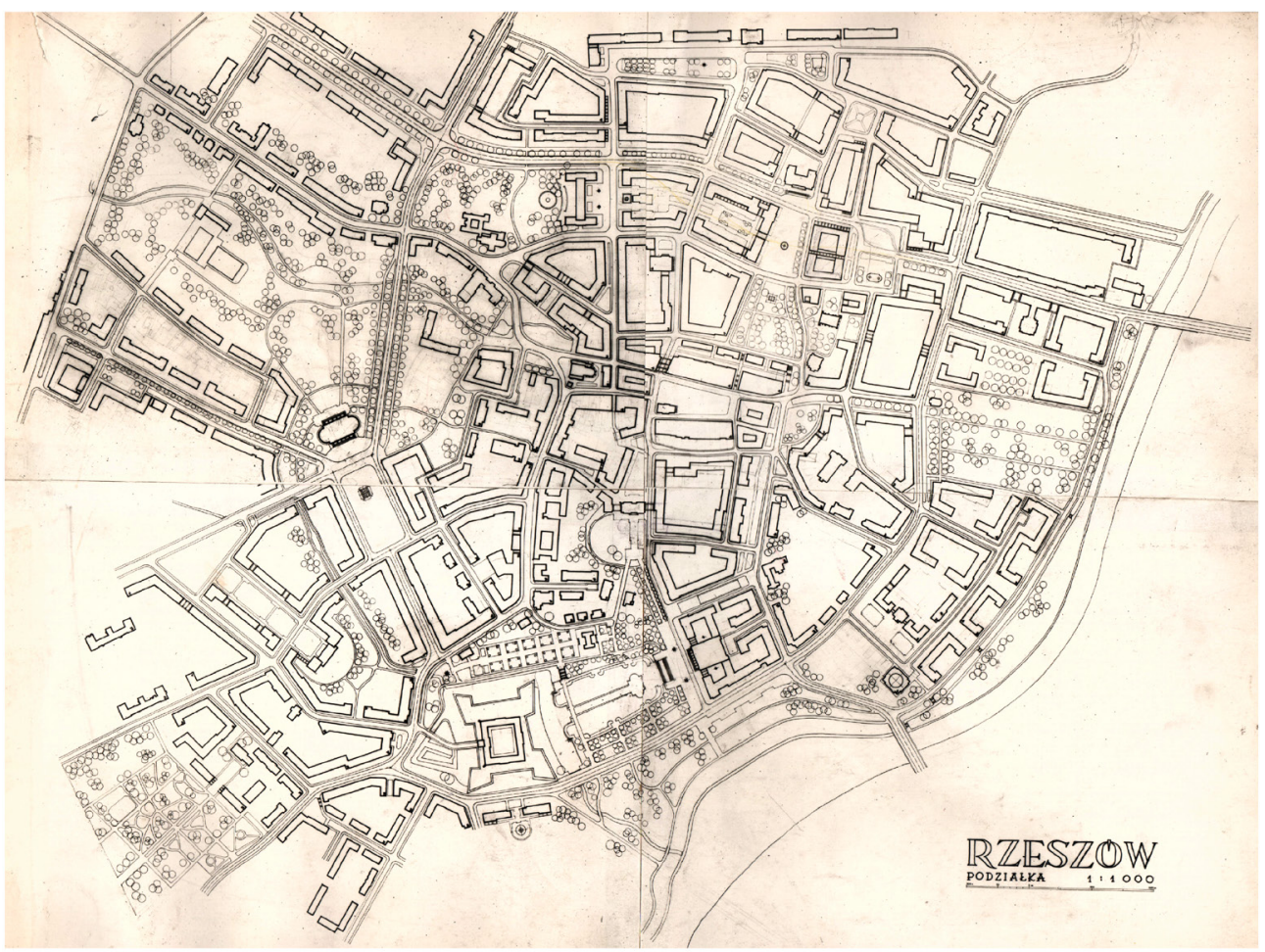

II. 5. Plan zagospodarowania Śródmieścia Rzeszowa autorstwa Z. Wzorka (źródło: Archiwum BRMRz) 


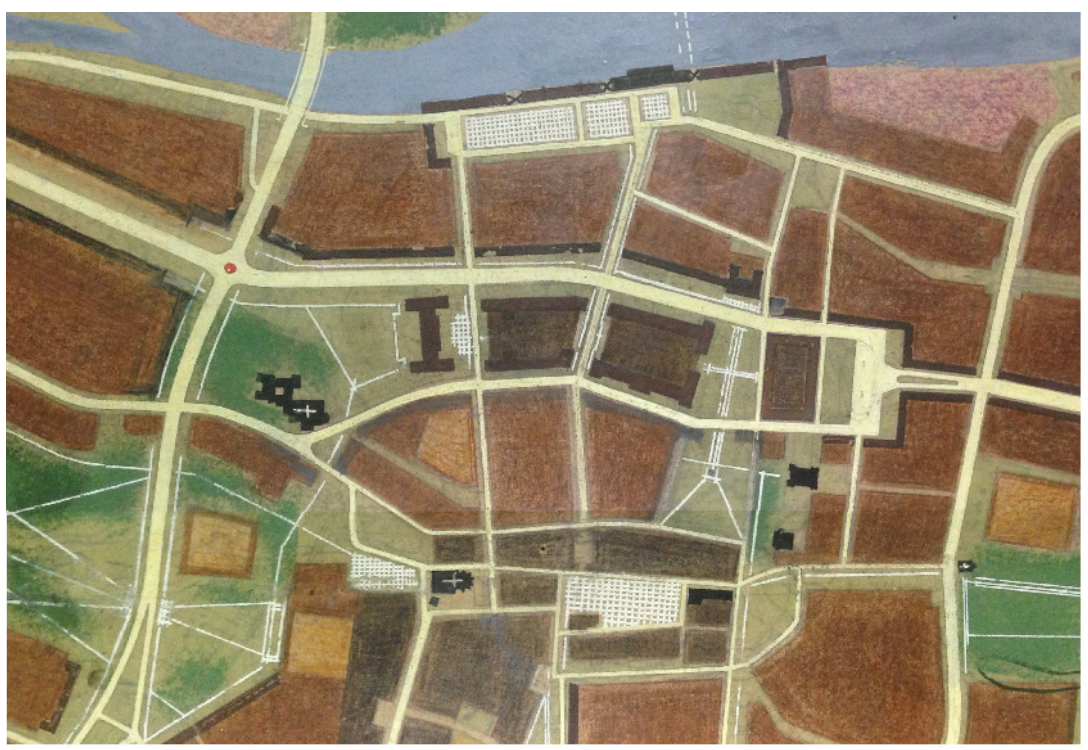

II. 6. Plan ogólny zagospodarowania przestrzennego Rzeszowa Z. Wzorka. Pasmo wschód-zachód zabudowy Śródmieścia (źródło: Archiwum BRMRz)

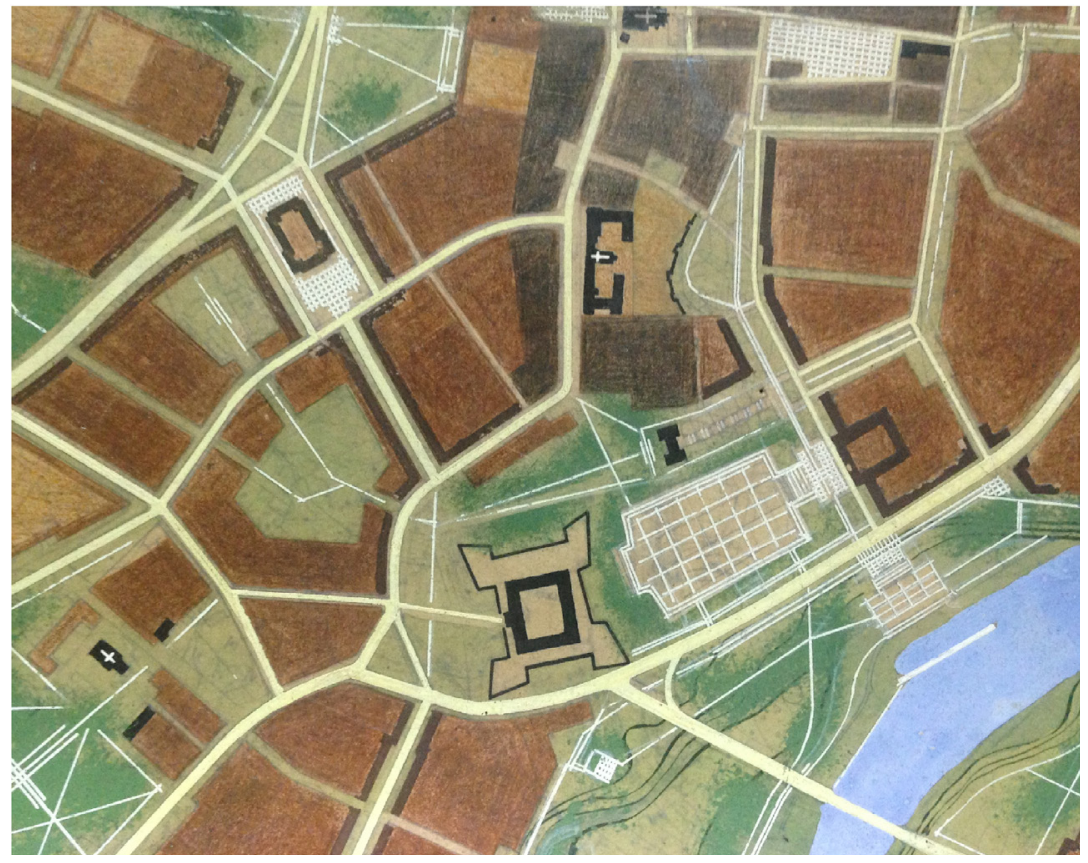

II. 7. Plan ogólny zagospodarowania przestrzennego Rzeszowa Z. Wzorka. Założenia urbanistyczne południowej części Śródmieścia (źródło: Archiwum BRMRz) 


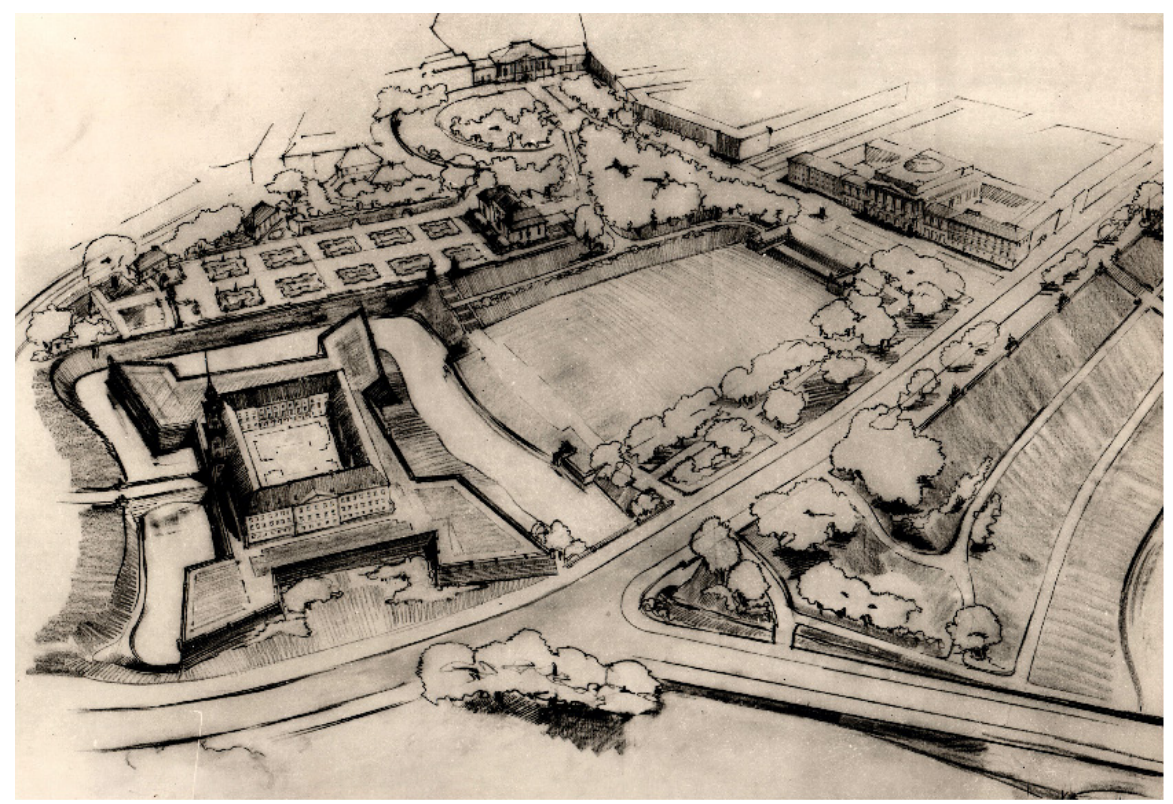

II. 8. Studium rysunkowe do planu zagospodarowania przestrzennego Śródmieścia Rzeszowa Z. Wzorka. Założenia urbanistyczne Zamek-Teatr (źródło: Archiwum BRMRz)

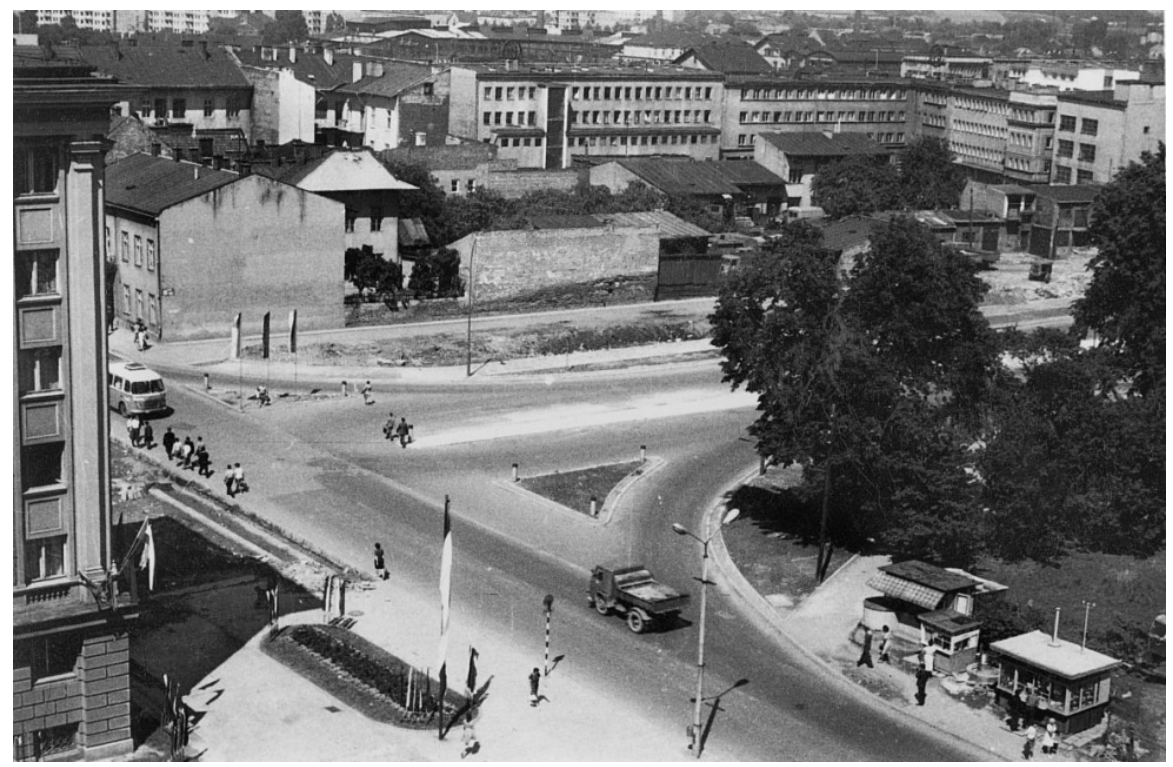

II. 9. Rzeszów. Skrzyżowanie ul. Grunwaldzkiej i al. Lenina (współcześnie al. Piłsudskiego). Lata 60. XX w. (źródło: Podkarpacka Historia, https://www.podkarpackahistoria.plgaleria7, rzeszowlat-60-xx-wieku, dostęp: 14.10.2020) 


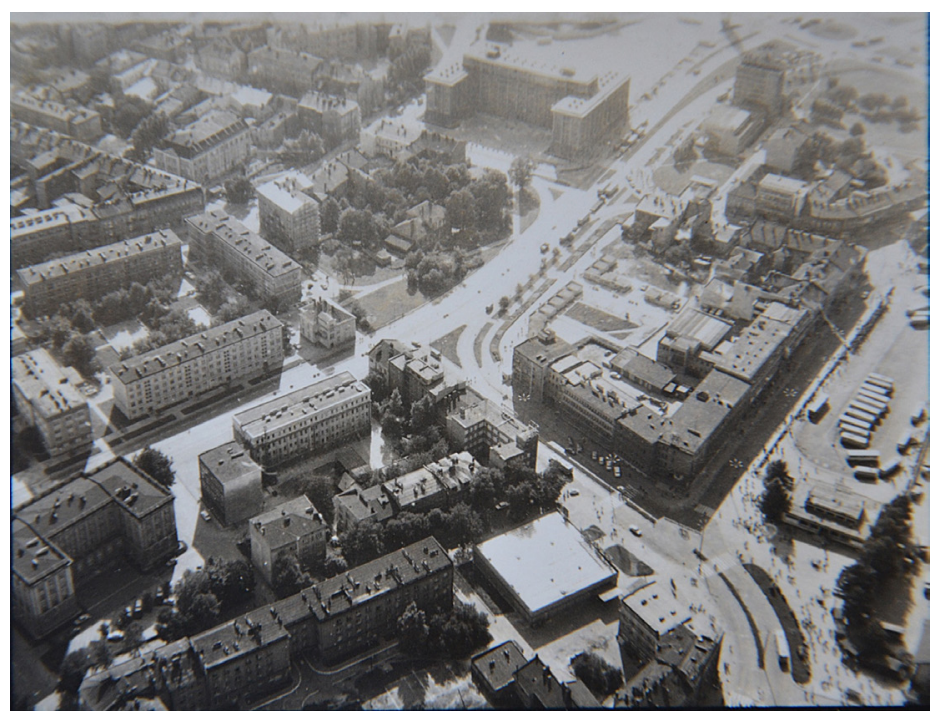

II. 10. Śródmieście Rzeszowa, lata 60. XX w. Rejon al. Lenina (obecnie al. Piłsudskiego), ul. Asnyka i ul. Grunwaldzkiej (źródło: Podkarpacka Historia, https://www.facebook. comRzeszowCAFphotosa.111812253823766152270283111296, dostęp: 14.10.2020)

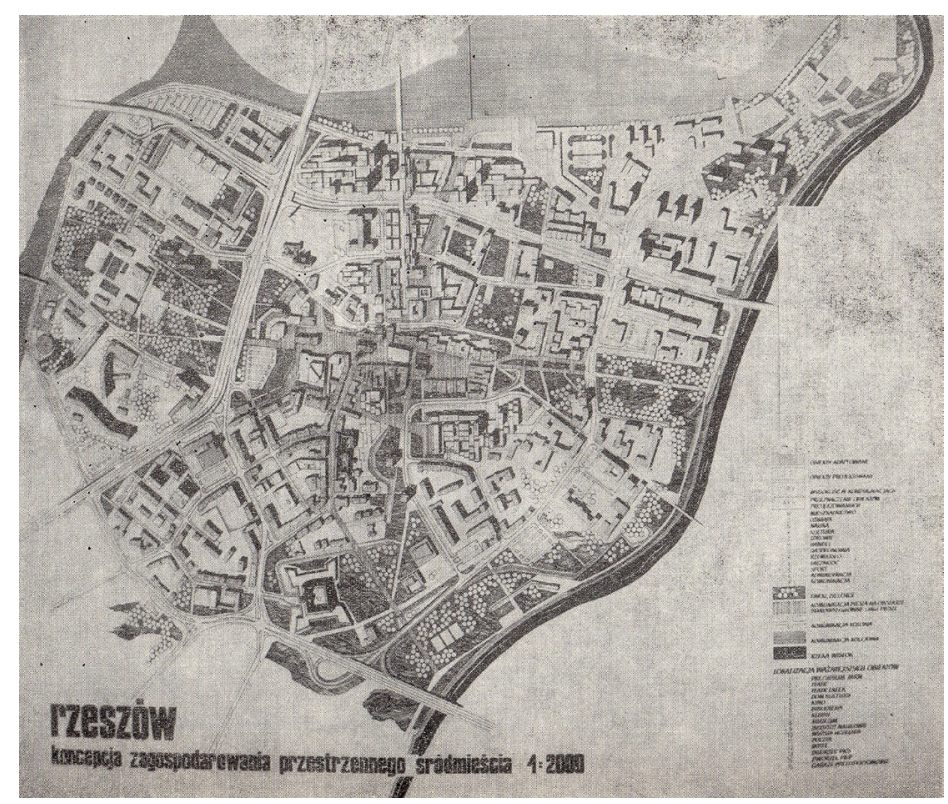

II. 11. Koncepcja zagospodarowania przestrzennego Śródmieście Rzeszowa. Pierwsza nagroda w Konkursie nr 520 SARP Centrum Rzeszowa (źródło: Konkurs nr 520 SARP Centrum Rzeszowa, Stowarzyszenie Architektów Polskich Oddział w Rzeszowie, Łańcut 1974, s. 99) 


\section{PRZYPISY}

1 Szerokie ujęcie historii i tematyki rozwoju przestrzennego miasta stanowią: Dzieje Rzeszowa, t. I, Rzeszów od najdawniejszych czasów do I rozbioru, red. F. Kiryk, KAW-Rzeszów, Rzeszów 1994; Dzieje Rzeszowa, t. II, Rzeszów w czasach zaborów i niewoli (1772-1918), red. F. Kiryk, KAW-Rzeszów, Rzeszów 1998; Dzieje Rzeszowa, t. III, Rzeszów w okresie międzywojennym i okupacji (1918-1944), red. F. Kiryk, Wydawnictwo Libri Ressovienses, Rzeszów 2001; Dzieje Rzeszowa, t. IV, Rzeszów w latach 1945-1989, red. W. Bonusiak, Urząd Miasta Rzeszowa, Rzeszów 2012.

2 Skorowidz Gmin Rzeczpospolitej Polskiej, Warszawa 1935.

3 Wywiad z Władysławem Hennigiem (przeprowadził T. Moskal), Rzeszów, 21.02.2014.

4 Z. Wzorek, Kompozycja Planu Śródmieścia, archiwum P. Wzorka, s. 18.

5 Ibidem, s. 11.

6 Z. Wzorek, Studium do Planu Miasta Rzeszowa, archiwum P. Wzorka, s. 12.

7 Ibidem, s. 12.

8 Z. Wzorek, Kompozycja..., op. cit., s. 1.

9 Ibidem, s. 11.

10 W. Hennig, Monografia opracowań urbanistycznych z lat 1938-1969 oraz rozwoju miasta, jaki miał miejsce w latach 1955-1969, Rzeszów 1969, część B, s. 19.

11 S. Juchnowicz, Śródmieścia miast Polskich. Studia nad ukształtowaniem i rozwojem centrów, Wrocław-Warszawa-Kraków-Gdańsk 1971, s. 37-38.

12 Ibidem, s. 6.

${ }^{13}$ Aktualne problemy urbanistyczne województwa rzeszowskiego, red. M. Mermon.

${ }^{14}$ Głos w dyskusji podczas Regionalnego Pokazu Architektury, jaki odbył się w Rzeszowie w dniach 21-27 października 1956, Biuletyn Komitetu do Spraw Urbanistyki i Architektury, nr 3 (8), Rok II-57, s. 13.

15 A. Galar, Sprawozdanie, Konkurs nr 520 SARP Centrum Rzeszowa, Stowarzyszenie Architektów Polskich Oddział w Rzeszowie, Łańcut 1974, s. 4.

16 L. Humięcki, Zamiast wstępu, Konkurs nr 520 SARP Centrum Rzeszowa, Stowarzyszenie Architektów Polskich Oddział w Rzeszowie, Łańcut 1974, s. 3.

17 J. Wijowski, Dyskusja, Konkurs nr 520 SARP Centrum Rzeszowa, Stowarzyszenie Architektów Polskich Oddział w Rzeszowie, Łańcut, 1974, s. 8. 


\section{BIBLIOGRAFIA}

Aleksiewicz M., Rzeszów w 20-leciu PRL, Prezydium Miejskiej Rady Narodowej i Towarzystwo Przyjaciół Nauki i Sztuki w Rzeszowie, Rzeszów 1965.

Biuletyn Komitetu do Spraw Urbanistyki i Architektury, nr 3 (8), Rok II-57.

Burger T., Społeczne skutki zmiany czynników miastotwórczych Rzeszowa. Wnioski dla planowania przestrzennego, Instytut Gospodarki Przestrzennej i Komunalnej, Warszawa 1986.

Dzieje Rzeszowa, t. I, Rzeszów od najdawniejszych czasów do I rozbioru, red. F. Kiryk, Krajowa Agencja Wydawnicza, Rzeszów 1994.

Dzieje Rzeszowa, t. II, Rzeszów w czasach zaborów i niewoli (1772-1918), red. F. Kiryk, KAW-Rzeszów, Rzeszów 1998.

Dzieje Rzeszowa, t. III, Rzeszów w okresie międzywojennym i okupacji (1918-1944), red. F. Kiryk, Wydawnictwo Libri Ressovienses, Rzeszów 2001.

Dzieje Rzeszowa, t. IV, Rzeszów w latach 1945-1989, red. W. Bonusiak, Urząd Miasta Rzeszowa, Rzeszów 2012.

Encyklopedia Rzeszowa, red. J. Draus, Rzeszów 2011.

Goldzamt E., Architektura zespołów śródmiejskich i problemy dziedzictwa, PWN, Warszawa 1956. Hennig W., Perspektywy rozwoju miasta [w:] Rzeszów w 20-leciu PRL, red. M. Aleksiewicz, Prezydium Miejskiej Rady Narodowej i Towarzystwo Przyjaciół Nauki i Sztuki w Rzeszowie, Rzeszów 1965.

Hennig W., Monografia opracowań urbanistycznych z lat 1938-1969 oraz rozwoju miasta, jaki miał miejsce w latach 1955-1969, Rzeszów 1969.

Hennig W., Opinia dotyczq̨ca programu i zadań badawczych dla ll etapu opracowania tematu „Podstawy kształtowania przestrzennego miast szybko rozwijajqcych się", opracowywanego w Zakładzie Planowania Miast Instytutu Urbanistyki i Architektury w Warszawie, Rzeszów 1971 (mps w zbiorach autora).

Hennig W., Struktura przestrzenna miasta Rzeszowa - ocena stanu istniejqcego i tendencji rozwojowych, Rzeszów 1971 (mps w Archiwum BRMRz).

Hennig W., Rola zieleni w kształtowaniu krajobrazu miejskiego na przykładzie miasta Rzeszowa, Rzeszów 1980 (mps w Archiwum BRMRz).

Hennig W., Rzeszów po czterdziestu latach, [w:] Rzeszów - moje miasto, Towarzystwo Przyjaciół Rzeszowa, Rzeszów 1984.

Humięcki L., Rozwój Rzeszowa jako siedziby województwa, „Miasto”, nr 5, 1976, s. 11-19.

Humięcki L., Plan rewaloryzacji zespołu staromiejskiego w Rzeszowie, Rzeszów 1979 (mps w Archiwum BRMRz).

Humięcki L., Rozwój Rzeszowa jako ośrodka wojewódzkiego, [w:] Problemy rozwoju ośrodków wojewódzkich w makroregionie południowo-wschodnim, red. B. Tazbir-Tomaszewska, Towarzystwo Urbanistów Polskich, Warszawa 1981. 
Humięcki L., Malisiewicz E., Woźniak W., Perspektywy rozwojowe miasta Rzeszowa, jako ośrodka ponadregionalnego, [w:] Rozwój Rzeszowa na przestrzeni dziejów. Przyczynek do historii miasta. Materiały na konferencję organizowanq przez Zakład Urbanistyki i Architektury Wydziału Budownictwa i Inżynierii Środowiska Politechniki Rzeszowskiej, Rzeszów 1995.

Idziemy naprzód, red. E. Jakubowska, Miejski Komitet Frontu Jedności Narodu w Rzeszowie, Rzeszów 1965.

„Informator Oddziału SARP w Rzeszowie” - notatki dotyczące konkursu na zagospodarowanie Rynku Starego Miasta w Rzeszowie w numerach: XII 2003, VII 2004, IV 2005.

Juchnowicz S., Śródmieścia miast Polskich. Studia nad ukształtowaniem i rozwojem centrów, Wrocław-Warszawa-Kraków-Gdańska 1971.

Kardyś A., Stan opracowań urbanistycznych dla potrzeb rewaloryzacji miast województwa rzeszowskiego, Wojewódzkie Biuro Planowania Przestrzennego w Rzeszowie, Rzeszów 1984.

Konkurs nr 520 SARP Centrum Rzeszowa, Materiały do użytku służbowego, Stowarzyszenie Architektów Polskich Oddział w Rzeszowie, Łańcut 1974.

Kotarski H., Malicki K., Stolica Podkarpacia wczoraj i dziś. Studium socjologiczne społecznych aspektów przemian w Rzeszowie w latach 1989-2009, Wydawnictwo Uniwersytetu Rzeszowskiego, Rzeszów 2013.

Kwiatkowski Z., Byłem niemilczq̨ym świadkiem, Iskry, Warszawa 1965.

Moskal T., Wpływ założeń Ogólnego Planu Zabudowania miasta Rzeszowa z 1939 roku na dokumenty planistyczne miasta w latach 1939-2003, Politechnika Krakowska, Kraków 2018. Niepublikowana rozprawa doktorska, promotor M. Motak.

Nowakowski M., Sto lat planowania przestrzeni polskich miast (1919-2010), Warszawa 2013. Rzeszów. Regionalny Pokaz Architektury 21-27 października 1956, Biuletyn Komitetu do Spraw Urbanistyki i Architektury, nr 3 (8), Rok II-57.

Skorowidz Gmin Rzeczpospolitej Polskiej, Warszawa 1935.

Wywiad z Władysławem Hennigiem (przeprowadził T. Moskal), Rzeszów, 21.02.2014.

Wzorek Z., Kompozycja Planu Śródmieścia, archiwum P. Wzorka.

Wzorek Z., Studium do planu miasta Rzeszowa, archiwum P. Wzorka. 